\title{
UJI AKTIVITAS ANTIFUNGAL EKSTRAK DAUN JOHAR (Cassia siamea Lamk) TERHADAP PERTUMBUHAN FUNGI Phytophthora palmivora
}

\author{
Yusup Indra Putra ${ }^{1)}$, Hasyim As'ari' ${ }^{2)}$, Tristi Indah Dwi Kurnia ${ }^{3)}$ \\ 1,2,3 Program Studi Biologi, Fakultas Matematika dan Ilmu Pengetahuan Alam \\ Universitas PGRI Banyuwangi \\ email: indrayusuf594@gmail.com
}

\begin{abstract}
Abstrak
Phytophthora palmivora adalah fungi penyebab busuk buah pada tanaman kakao. Kerusakan yang diakibatkan oleh fungi ini adalah menurunya hasil panen hingga $90 \%$. Penelitian ini bertujuan untuk mengetahui adanya pengaruh pemberian ekstrak daun tanaman johar (Cassia Siamea Lamk) terhadap pertumbuhan fungi Phytophthora palmivora. Jenis penelitian ini adalah eksperimental laboratoris dengan metode RAL dengan 3 kali ulangan dan 7 perlakuan. Hasil analisis data menunjukan adanya pengaruh antara konsentrasi ekstrak daun tanaman johar (Cassia Siamea Lamk) terhadap pertumbuhan fungi Phytopthora palmivora dengan berbeda signifikan pada tiap-tiap konsentrasinya. Konsentrasi ekstrak daun tanaman johar (Cassia Siamea Lamk) yang paling efektif adalah 50\% dengan rata-rata diameter zona hambat sebesar $1.34 \mathrm{~cm}$.
\end{abstract}

Keywords: Phytophthora palmivora; ekstrak daun tanaman johar (Cassia Siamea Lamk)

\section{PENDAHULUAN}

Tahun 2010 Indonesia tercatat menjadi salah satu pengekspor biji kakao (Theobroma cacao) terbesar ketiga dunia. Namun peningkatan luasan perkebunan ternyata tidak diimbangi dengan produktivitas biji kakao yang cenderung mengalami penurunan. Penurunanan tersebut dipengaruhi oleh banyak faktor seperti adanya infeksi penyakit yang menyebabkan busuk buah kakao (Rubiyo, et.al 2012).

Infeksi tersebut disebabkan oleh fungi Phytophthora palmivora (Nurfianti, et.al 2019). Umumnya pengendalian fungi yang dilakukan dengan menggunakan fungisida sintetis. Akan tetapi penggunaan fungisida sintesis memiliki dampak negatif bagi lingkungan dan kesehatan. Berdasarkan hal tersebut, maka diperlukan suatu metode pengendalian infeksi penyakit kakao yang ramah lingkungan seperti fungisida nabati.

Fungisida nabati merupakan fungisida yang berasal dari berbagai senyawa dari bagian organ tamanan yang dapat memiliki aktivitas antifungal. Salah satu tanaman

Uji Aktivitas Antifungal Ekstrak Daun Johar (Cassia siamea lamk) terhadap Pertumbuhan Fungi phytophthora palmivora 
yang yang berpotensi sebagai fungisida nabati yaitu daun tanaman johar (Cassia siamea Lamk.).

Menurut Smith (2009), tanaman johar (Cassia siamea Lamk.) juga mengandung senyawa metabolit seperti saponin, antrakuinon, flavonoid, alkaloid, dan tannin. Dewi, et.al (2019), menyatakan bahwa kandungan senyawa metabolit seperti saponin, flavanoit, tanin dan alkaloid yang terkandung pada tanaman dapat digunakan sebagai antifungal. Penelitian sebelumnya yang dilakukan oleh Purwanto, (2018), menunjukkan bahwa ekstrak metanol daun johar (Cassia siamea Lamk.) efektif dalam menghambat pertumbuhan jamur Saprolegnia sp Serta penelitian yang dilakukan oleh Pine, et.al (2018), menunjukkan bahwa krim ekstrak daun johar (Cassia siamea Lamk.) memberikan penghambatan terhadap pertumbuhan fungi Candida albicans.

Tujuan dari penelitian ini adalah untuk mengetahui efektivitas ekstrak daun tanaman johar dalam menghambat pertumbuhan fungi Phytophtora palmivora, selain itu, tujuan dari penelitian ini adalah untuk menentukan KHM (Konsentrasi Hambat Minimal) ekstrak daun tanaman johar.

\section{METODE PENELITIAN}

Penelitian ini menggunakan Rancangan Acak Lengkap (RAL) dengan 3 kali ulangan, untuk proses pengujian dilakukan secara in vitro dengan metode sumuran. Setiap sumuran di isi dengan ekstrak daun tanaman johar. Serial konsentrasi yang digunakan sebesar; 10\%, 20\%, 30\%, 40\% dan 50\%. Setelah didapatkan hasil dari uji sebelumnya, kemudian dilakukan pengenceran untuk menentukan Konsentrasi Hambat Minimal (KHM), serial konsentrasi yang digunakan sebesar; 10\%, 12,5\%, 15\%, 17,5\% dan $20 \%$. Kontrol positif menggunakan ketoconazole $1 \%$ dan kontrol negatif aquades steril.

Penelitian dilakukan dengan cara mengambil $100 \mu \mathrm{l}$ suspensi Phytophthora Palmivora. yang telah dibuat kemudian diteteskan pada tabung reaksi yang berisi medium yang masih cair kemudian divortek selanjutnya dituang di dalam cawan petri steril. Lalu membuat lubang atau sumuran yang dibuat pada permukaan media yang Uji Aktivitas Antifungal Ekstrak Daun Johar (Cassia siamea lamk) terhadap Pertumbuhan Fungi | 2 phytophthora palmivora 
sudah ditaburi Phytophthora Palmivora. sebanyak 7 lubang dengan menggunakan pencetak agar yang sudah disterilkan dengan diameter $0,5 \mathrm{~cm}$. Isi tiap lubang dengan ekstrak daun johar dengan konsentrasi 10\%, 20\%, 30\%, 40\%, 50\%, dan menggunakan kontrol negatif berupa aquades steril, sedangkan kontrol positif menggunakan fungisida dengan konsentrasi $0,1 \%$ kemudian inkubasi pada suhu $30{ }^{\circ} \mathrm{C}$ selama 96 jam.

Setelah diinkubasi selama 96 jam, pengaruh ekstrak daun johar terhadap pertumbuhan fungi Phytophthora Palmivora. dapat dilihat dengan mengukur diameter zona bening yang terbentuk di sekitar lubang sumuran yang merupakan zona hambatan dengan menggunakan jangka sorong. Pengukuran diameter zona hambat ditentukan dengan cara berikut: Diameter hambatan $=\mathrm{d}_{2}-\mathrm{d}_{1}$

Keterangan : $\mathrm{d}_{1}=$ diameter lubang

$$
\mathrm{d}_{2}=\text { diameter zona bening }
$$

Data hasil penelitian kemudian dianalisis secara statistik menggunakan uji Anova pada tingkat kepercayaan 95\%, kemudian dilanjutkan dengan uji Duncan.

\section{HASIL DAN PEMBAHASAN}

Hasil identifikasi fungi Phytopthora palmivora dengan pengamatan secara makroskopis didapatkan koloni fungi berwarna putih berkoloni dengan struktus seperti serabut kapas. Secara mikroskopis fungi Phytopthora palmivora memiliki hifa yang tidak bersekat, tidak bercabang dan tidak berwarna atau transparan. Bentuk sporangium seperti buah pear terdapat papilla pada ujungnya, dan memiliki miselium. Adapun Gambar hasil identifikasi fungi Phytopthora palmivora secara mikroskopik dapat dilihat pada Gambar dibawah ini. 


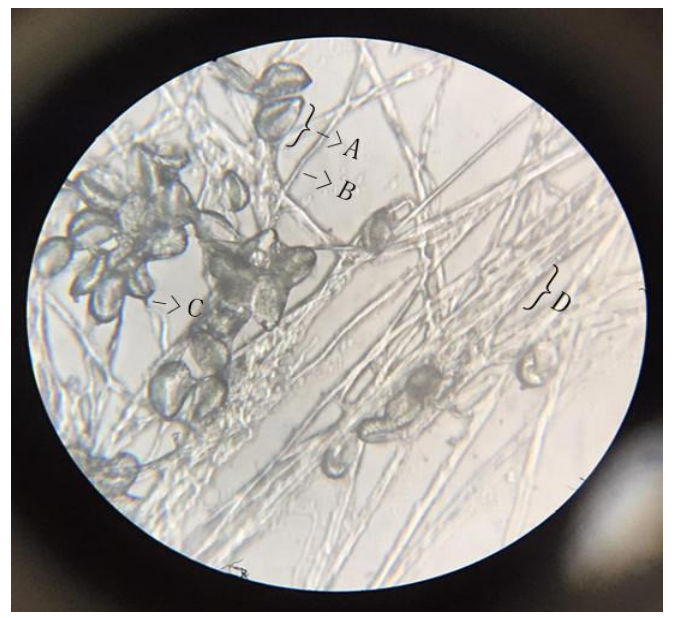

Gambar 1 Hasil pengamatan secara mikroskopik fungi Phytopthora palmivora Keterangan:
A : Sporangium
B : Hifa
C : Papilla
D : Miselium

Hasil uji pengaruh ekstrak daun tanaman johar (Cassia Siamea Lamk) terhadap pertumbuhan fungi Phytopthora palmivora dapat dilihat pada Gambar dan Tabel dibawah ini.

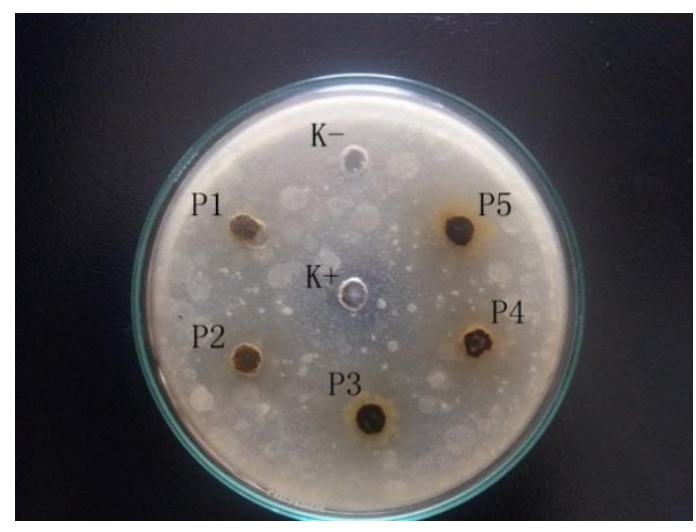

Gambar 2 Zona hambat ekstrak daun tanaman johar terhadap pertumbuhan fungi Phytopthora palmivora 
Keterangan:

$\mathrm{K}+$ : Ketoconazole $0,1 \%$

$\mathrm{K}-$ : Aquades steril

P1 : Ekstrak daun johar 10\%

P2 : Ekstrak daun johar 20\%

P3 : Ekstrak daun johar 30\%

P4 : Ekstrak daun johar 40\%

P5 : Ekstrak daun johar 50\%

Tabel 1 Hasil pengukuran zona hambat ekstrak daun tanaman johar terhadap fungi Phytopthora palmivora.

\begin{tabular}{cccccc}
\hline No & Perlakuan & U1 & U2 & U3 & $\begin{array}{c}\text { Rata- } \\
\text { rata }\end{array}$ \\
\hline $\mathbf{1}$ & K- & 0,00 & 0,00 & 0,00 & 0,00 \\
$\mathbf{2}$ & K+ & 0,41 & 0,49 & 0,43 & 0,44 \\
$\mathbf{3}$ & P1 & 0,00 & 0,00 & 0,00 & 0,00 \\
$\mathbf{4}$ & P2 & 0,14 & 0,17 & 0,10 & 0,13 \\
$\mathbf{5}$ & P3 & 0,46 & 0,41 & 0,39 & 0,42 \\
$\mathbf{6}$ & P4 & 0,62 & 0,70 & 0,63 & 0,65 \\
$\mathbf{7}$ & P5 & 1,27 & 1,37 & 1,39 & 1,34 \\
\hline
\end{tabular}

Keterangan:

$\mathrm{K}+$ : Ketoconazole 0,1\%

$\mathrm{K}-$ : Aquades steril

P1 : Ekstrak daun johar 10\%

P2 : Ekstrak daun johar 20\%

P3 : Ekstrak daun johar 30\%

P4 : Ekstrak daun johar 40\%

P5 : Ekstrak daun johar 50\%

Berdasarkan Tabel 1 menunjukan bahwa perlakuan (P1, P2, P3, P4, dan P5) memberikan pengaruh yang berbeda-beda pada setiap zona hambat fungi Phytopthora palmivora. Dimana rata-rata diameter zona hambat terbesar ditunjukan pada konsentrasi $50 \%$ yaitu sebesar $1,34 \mathrm{~cm}(13,4 \mathrm{~mm})$, hal tersebut menunjukkan menunjukan zona hambat perlakuan (P5) disekitar 10-20 mm, sehingga dapat 
dikategorikan kuat (Ardiansyah, 2005). Rata-rata diameter zona hambat pada perlakuan P4 (konsentrasi $40 \%)$ yaitu sebesr $0,65 \mathrm{~cm}(6,5 \mathrm{~mm})$ hal tersebut menunjukan bahwa diameter zona hambat berada dikisaran 5-10 $\mathrm{mm}$ yang dapat dikategorikan sedang (Ardiansyah, 2005). Sedangkan pada perlakuan P2, P3, dan K+ didapatkan rata-rata diameter zona hambat dikisaran 0,13-0,44 cm (1,3-4,4 mm), yang dapat dinyatakan masih dibawah $5 \mathrm{~mm}$, sehingga pada perlakuan-perlakuan tersebut dikategorikan memiliki zona hambat yang lemah (Ardiansyah, 2005).

Berdasarkan hasil analisis ANOVA yang ditunjukan dengan nilai signifikansi sebesar 0,000 sehingga lebih kecil dari 0,05 $(\mathrm{P}<0,05)$ dan $\mathrm{F}_{\text {Hitung }}$ lebih besar dari $\mathrm{F}_{\text {Tabel }}$ $(454,885>2,85)$, hal tersebut dapat diartikan bahwa perlakuan pemberian ekstrak daun tanaman johar (Cassia Siamea Lamk) merupakan faktor yang menghambat pertumbuhan fungi Phytopthora palmivora.

Berdasarkan hasil uji Duncan, zona hambat perlakuan 10\%, 20\%, 30\%, 40\%, dan $50 \%$ berada pada kolom yang berbeda, hal tersebut menunjukan bahwa perlakuanperlakuan tersebut berbeda nyata atau signifikan. Sedangkan $\mathrm{K}+$ (kontrol positif ketoconazole $0,1 \%$ ) berada di satu kolom dengan perlakuan $30 \%$ hal tersebut menunjukkan bahwa tidak berbeda nyata atau tidak signifikan dengan perlakuan $30 \%$, namun $\mathrm{K}+$ berbeda nyata atau signifikan dengan perlakuan lainya. Berdasarkan hasil uji Duncan menunjukan bahwa konsentrasi perlakuan ekstrak daun tanaman johar (Cassia Siamea Lamk) dengan range (jarak) 10\% menunjukan tingkat penghambatan terhadap fungi Phytopthora palmivora yang nyata, dengan peningkatan konsentrasi perlakuan akan berpengaruh terhadap peningkatan zona hambat yang terbentuk. Hal tersebut sesuai dengan pernyataan As'ari, et al (2016), bahwa peningkatan konsentrasi senyawa antimikrobial pada suatu ekstrak tanaman, juga akan diikuti dengan peningkatan senyawa metabolit yang terlarut didalamnya, sehingga memungkinkan terjadinya peningkatan zona hambat yang terbentuk pada mikroba uji.

Senyawa metabolisme yang terdapat pada tanaman johar (Cassia siamea Lamk) secara mandiri maupun kombinasi dapat menghambat pertumbuhan sel fungi 
Phytopthora palmivor. Dimana kandungan senyawa saponin yang terdapat pada tanaman johar (Cassia siamea Lamk) dapat menurunkan konsentrasi permukaan dinding sel dan merusak permeabilitas membrane sel fungi (Ningrum, et al. 2017). Sedangkan kandungan senyawa flavonoid dapat mendenaturasi protein membran yang menyebabkan gangguan dalam pembentukan sel sehingga merubah komposisi komponen protein, selain itu denaturasi protein juga menyebabkan fungsi membran sel terganggu dan mengakibatkan meningkatnya permeabilitas membran sel sehingga terjadi kerusakan sel fungi (Srinigsih, 2008). Putri, (2015) menjelaskan bahwa kandungan senyawa tannin yang terdapat pada tanaman dapat menghambat pertumbuhan fungi dengan cara menghambat sintesis khitin yang digunakan untuk pembentukan dinding sel dan merusak membran sel sehingga pertumbuhan fungi terhambat. Sedangkan kandungan senyawa alkaloid yang terkandung dalam tanaman johar (Cassia Siamea Lamk) dapat menghambat pertumbuhan sel fungi dengan cara terjadinya ikatan senyawa alkaloid dan ergosterol, yang berdampak terhadap pembentukan lubang dan mengakibatkan kebocoran pada membrane sel fungi (Setiabudy, et al.2008).

Hasil uji Konsentrasi Hambat Minimal (KHM) dapat dilihat pada Gambar dan Tabel dibawah ini.

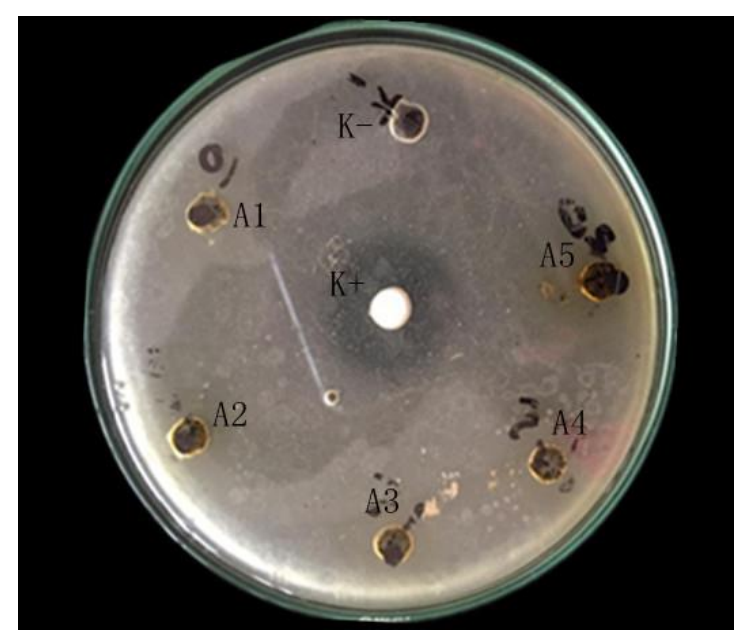

Gambar 3 hasil uji Konsentrasi Hambat Minimal (KHM).

Uji Aktivitas Antifungal Ekstrak Daun Johar (Cassia siamea lamk) terhadap Pertumbuhan Fungi phytophthora palmivora 
Keterangan:

$\mathrm{K}+$ : Ketoconazole $1 \%$

$\mathrm{K}$ - : Aquades steril

A1 : Ekstrak daun johar $10 \%$

A2 : Ekstrak daun johar 12,5\%

A3 : Ekstrak daun johar 15\%

A4 : Ekstrak daun johar 17,5\%

A5 : Ekstrak daun johar 20\%

Tabel 2 Hasil uji Konsentrasi Hambat Minimal (KHM).

\begin{tabular}{llllll}
\hline No & perlakuan & U1 & U2 & U3 & $\begin{array}{l}\text { Rata- } \\
\text { rata }\end{array}$ \\
\hline $\mathbf{1}$ & K- & 0,00 & 0,00 & 0,00 & 0,00 \\
$\mathbf{2}$ & K+ & 1,67 & 2,25 & 2,26 & 2,06 \\
$\mathbf{3}$ & P1 & 0,00 & 0,00 & 0,00 & 0,00 \\
$\mathbf{4}$ & P2 & 0,02 & 0,01 & 0,01 & 0,013 \\
$\mathbf{5}$ & P3 & 0,05 & 0,04 & 0,04 & 0,043 \\
$\mathbf{6}$ & P4 & 0,10 & 0,09 & 0,09 & 0,093 \\
$\mathbf{7}$ & P5 & 0,15 & 0,12 & 0,13 & 0,133 \\
\hline
\end{tabular}

Keterangan:

$\mathrm{K}+$ : Ketoconazole $1 \%$

$\mathrm{K}$ - : Aquades steril

A1 : Ekstrak daun johar 10\%

A2 : Ekstrak daun johar 12,5\%

A3 : Ekstrak daun johar $15 \%$

A4 : Ekstrak daun johar 17,5\%

A5 : Ekstrak daun johar 20\%

Berdasarkan Tabel 2 diatas menunjukan bahwa zona hambat ekstrak daun tanaman johar (Cassia Siamea Lamk) terbentuk pada konsentrasi K+, A2, A3, A4, dan A5. Konsentrasi yang memiliki zona hambat paling besar adalah $20 \%$ dengan dengan ratarata diameter zona hambat sebesar $0,133 \mathrm{~cm}$, sedangkan konsentrasi yang memiliki zona hambat terkecil adalah $12,5 \%$ dengan rata-rata dimeter zona hambat sebesar 0,013 $\mathrm{cm}$. Kandungan senyawa metabolit seperti saponin, flavonoid, tanin dan alkaloid pada 
KHM ekstrak daun tanaman johar (Cassia Siamea Lamk) (konsentrasi 12,5\%) terkandung relatif paling sedikit dan masih menunjukkan penghambatan pada fungi Phytopthora palmivora. hal tersebut didukung dengan pernyataan (As'ari, et al,. 2016), menyatakan bahwa peningkatan dan penurunan konsentrasi perlakuan berbanding dengan kandungan senyawa metabolit tanaman yang terlarut didalamnya, sehingga ketika senyawa metabolit yang terkandung terlalu rendah dimungkinkan penghambatan terhadap mikroorganisme tidak terbentuk.

\section{KESIMPULAN DAN SARAN}

\subsection{Kesimpulan}

1. Terdapat perngaruh antara ekstrak daun tanaman johar (Cassia Siamea Lamk) terhadap pertumbuhan fungi phytopthora palmivora.

2. Ekstrak daun tanaman johar (Cassia Siamea Lamk) memperlihatkan aktivitas pada Konsentrasi Hambat Minimal (KHM) 12,5\% dengan rata-rata diameter zona hambat sebesar $0,013 \mathrm{~cm}$.

\subsection{Saran}

1. Ekstrak daun tanaman johar (Cassia Siamea Lamk) perlu dilakukan konsentrasi yang lebih tinggi agar lebih efektif dalam menghambat fungi phytopthora palmivora.

2. Perlu dilakukan penelitian lanjutan terkait senyawa metabolit yang terkandung dalam ekstrak daun tanaman johar (Cassia Siamea Lamk) dalam menghambat fungi phytopthora palmivora.

\section{REFERENSI}

As'ari, H., Kurnia, T. I., \& Nurchayati, N. (2016). Aktivitas Antimicrobial Ekstrak Etanol Biji Ganitri (Elaeocarpus). bioedukasi, 16.

Ardiansyah. 2005. Antimikroba dari Tumbuhan. (Bagian kedua) Available from; http://www.beritaiptek.com (diakses pada tanggal 12 Februari 2021). 
Dewi, Ni Luh P S S, S, Dewa N, S, I Ketut. (2019). Uji Efektivitas Ekstrak Daun Cengkeh (Syzygium Aromaticum L.) Terhadap Phytophthora Palmivora Penyebab Penyakit Busuk Buah Kakao (Theobroma Cacao L.). Jurnal Agroekoteknologi Tropika, 8(4), 458-467.

Ningrum, D. W, Kusrini, D. \& Fachriyah E. (2017). Uji Aktivitas Antioksidan Senyawa Flavonoid dari Ekstrak Etanol Daun Johar (Cassia siamea Lamk). Jurnal Kimia Sains dan Aplikasi, 20(3), 123-129.

Nurfianti, \& Umrah. (2019). Pengamatan Gejala Infeksi Phytophthora palmivora Penyebab Penyakit Busuk Buah pada Kakao. Biocelebes, 13(3), 253-261.

Pine, Andi, T. D. A. Arief, D. Ika Riski (2018). Potensi Krim Ekstrak Daun Johar (Cassia siamea Lamk) Menghambat Pertumbuhan Candida albicans. Jour.Pharm.Sci, 1(1), 42-48.

Purwanto, Ridwan Y.(2018). Uji Aktivitas Antijamur Ekstrak Daun Johar (Cassia siamea Lamk.) terhadap Pertumbuhan Jamur Patogen Saprolegnia sp. http://digilib.uinsuka.ac.id/34090/1/11640010\%20BAB\%20I_BAB\%20V_DAFTAR\%20PUS TAKA.pdf [27 juli 2020].

Putri AMS (2015). Efek Antifungi Ekstrak Daun Kenikir (Cosmos caudatus Kunth.) Terhadap Pertumbuhan Candida Albicans Secara In Vitro. Skripsi. Surakarta: Fakultas Kedokteran Universitas Sebelas Maret Surakarta.

Rubiyo, \& Siswanto. (2012). Peningkatan Produksi Dan Pengembangan Kakao (Theobroma cacao L.) di Indonesia. Buletin RISTRI, 3(1), 33-48.

Setiabudy, \& Bahary. (2008). Farmakologi dan Terapi. Jakarta: Balai Penerbit FKUI.

Smith, Y.R.A (2009). Determination of Chemical Composition of Senna siamea (Cassia leaves). Pakistan Journal of Nutrition, 119-121.

Sriningsih. 2008. Analisa Senyawa Golongan Flavonoid Herba Tempuyung (SonchusarvensisL): www.indomedia.com/intisari/1999/juni/tempuyung.htm. (diakses tanggal 11 Juli 2020) 